\title{
THE WitTELSBACH BLUE
}

\author{
Rudolf Dröschel, Jürgen Evers, and Hans Ottomeyer
}

The 35.56 ct Wittelsbach Blue is one of the largest historic blue diamonds ever fashioned. It belonged to the Bavarian House of Wittelsbach and was displayed in the Treasury of the Munich Residence until it disappeared in 1931. It was secretly sold in 1951, "rediscovered" in 1961, and then sold again in 1964 to an undisclosed private buyer. In December 2008, the Wittelsbach Blue was sold at Christie's London to jeweler Lawrence Graff for just over \$24.3 million, a record price for any diamond at auction. This article describes what is known about the Wittelsbach Blue since it was first reported in 1666, and the gemological information released to date on this diamond, which was recently graded Fancy Deep grayish blue. Investigations in the historical archives of Bavaria, Austria, and Spain revealed that there is no archival evidence to support many previous statements about this stone.

$\mathrm{D}$ ue to their extreme rarity, blue diamonds, even more than colorless ones, have historically epitomized rank and wealth. Two of the largest known blue diamonds were once part of the crown jewels of European monarchies. The Hope diamond (now $45.52 \mathrm{ct}$ ) once belonged to the French royal family (Kurin, 2006), and the Wittelsbach Blue (now $35.56 \mathrm{ct}$, figure 1) was owned by the Bavarian royal family, the House of Wittelsbach.

Like the Hope, the Wittelsbach Blue is an intense steely blue. It is widely accepted that both originated from the Kollur mine in India's Golconda District (Bauer, 1932; Balfour, 1987). According to its previously published history (e.g., Gaal, 1977; Bruton, 1981, Balfour, 1997; Morel, 2001; Christie's, 2008a,b), the Wittelsbach Blue arrived in Vienna in 1666 as part of a dowry for a marriage into the House of Hapsburg. In 1722, it passed to the House of Wittelsbach in Munich, again as part of a dowry. It was mounted as a "symbol of dominion and power" (de Smet, 1963, p. 48) on the globe above the Bavarian Royal Crown around 1806 or 1807 (figure 2). During the 20th century, the Wittelsbach Blue was involved in a series of unusual events, which began in 1931 when the Wittelsbach Equity Foundation (German acronym WAF, for Wittelsbacher Ausgleichsfonds) tried in vain to sell it at the Christie, Manson \& Woods auction house in London (Christie, Manson
\& Woods, 1931). From the day of the auction through the next 30 years, the whereabouts of the Wittelsbach Blue were kept secret from the public. In 1951, the WAF secretly sold the Wittelsbach Blue, which was then "rediscovered" in 1961 by Antwerp diamond dealer Jozef Komkommer. In 1964, it was purchased by a private German collector whose identity was not revealed until recently.

During the authors' investigations in the Bavarian State Archive in Munich, in the Austrian State Archives in Vienna, and in three Spanish historical archives in Madrid, Simancas, and Valladolid, it became evident that many of the accepted "facts" about the Wittelsbach Blue and its history that were published by Antwerp diamond specialist K. de Smet in his book, The Great Blue Diamond, The Wittelsbacher, Crown Witness to Three Centuries of European History (1963), and cited afterwards by many others, had no archival basis. Based on our comprehensive review of the available documents, we can now correct the historical record and report on the true, exciting history of the Wittelsbach Blue as it moved through Europe.

See end of article for About the Authors and Acknowledgments. Gems \& Gemologr, Vol. 44, No. 4, pp. 348-363.

(C) 2008 Gemological Institute of America 


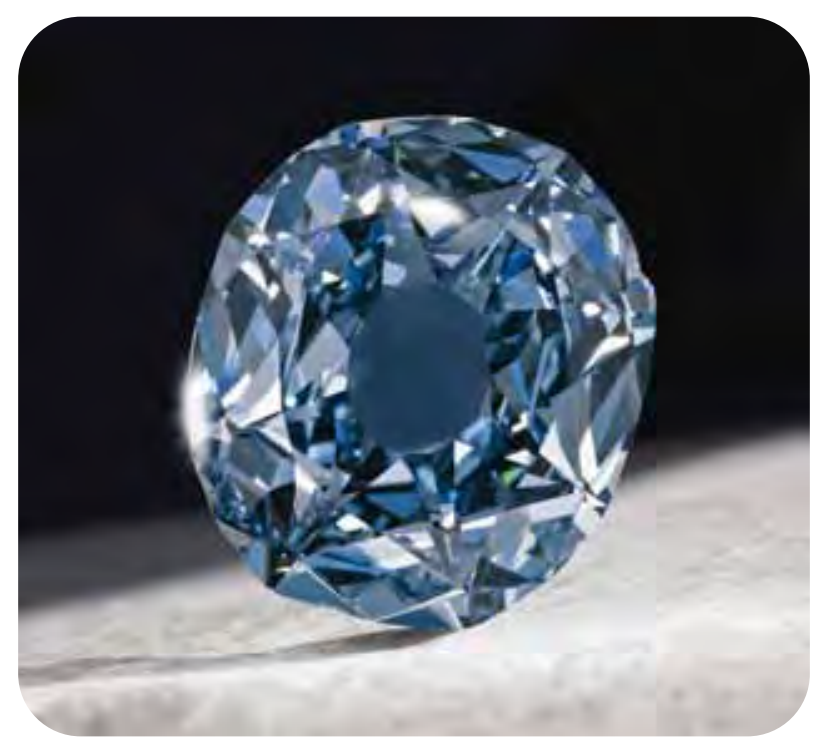

Figure 1. The Wittel sbach Blue (35.56 ct) is one of the largest and most famous blue diamonds in the world, with a known provenance that stretches back to the 17th century. Largely out of the public eye for more than 40 years, it was sold in December 2008, earning a record price for any diamond at auction. Photo courtesy of Christie's.

\section{INDIAN ORIGINS}

India was the world's only source of diamonds (Untracht, 1997) until about 1725 (Balfour, 1987), when the first Brazilian mines began to open (Legrand, 1981). Thus, all diamonds in Europe before that date, including the Wittel sbach Blue, must have had their origin in India (Harlow, 1998; Webster, 1994). M ost of India's diamonds, and its largest, were found in a vast area on the eastern side of the Deccan plateau (Bharadwaj, 2002). Many of these diamond sources were located in the former kingdom of Golconda, which lay between the rivers Godavari in the north and Pennar in the south.

Jean Baptiste Tavernier (1605-89), the famed French diamond dealer, visited three mines in the Golconda region between 1630 and 1668, among them Coulour (also spelled Kollur). This famous mine was the source of several historic diamonds, including the Koh-i-N oor, the Hope, the Dresden Green, the Orlov, the Regent, and the Sancy (Kurin, 2006). According to Bauer (1932), it was also the source of "nice blue diamonds." Balfour (1987, p. 112) wrote that the "Kollur mine, then, appears to be the only ... known source of Type Ilb natural blue diamonds" in India. Theidentity of the party who brought the Wittelsbach Blue (perhaps still in rough form) to Europe has been lost to the mists of history, but Tavernier is a possibility, given thetiming of its arrival.

\section{DOWRY OF AN EMPRESS}

Madrid. In his book, de Smet (1963) reported the findings of "Dr. Klaus Schneider, M unich," who was engaged by Jozef Komkommer to investigate the history of the Wittelsbach Blue after he had purchased the stone in 1961 (Burgerwelzijn, 1962). Schneideraccording to de Smet-was then a final-year doctoral student of history at Ludwig-M aximilian University

Figure 2. King Ludwig I of Bavaria (1786-1868) is shown here in 1826 in his coronation robes. The Bavarian crown with the Wittelsbach Blue is at his right. The crown and the right hand of the king (hol ding a scepter) rest on the Bavarian constitution. Painted by Joseph Karl Stieler (1781-1858), this portrait now hangs in the Neue Pinakothek museum in Munich. Courtesy of The Bavarian State Painting Collections, Munich.

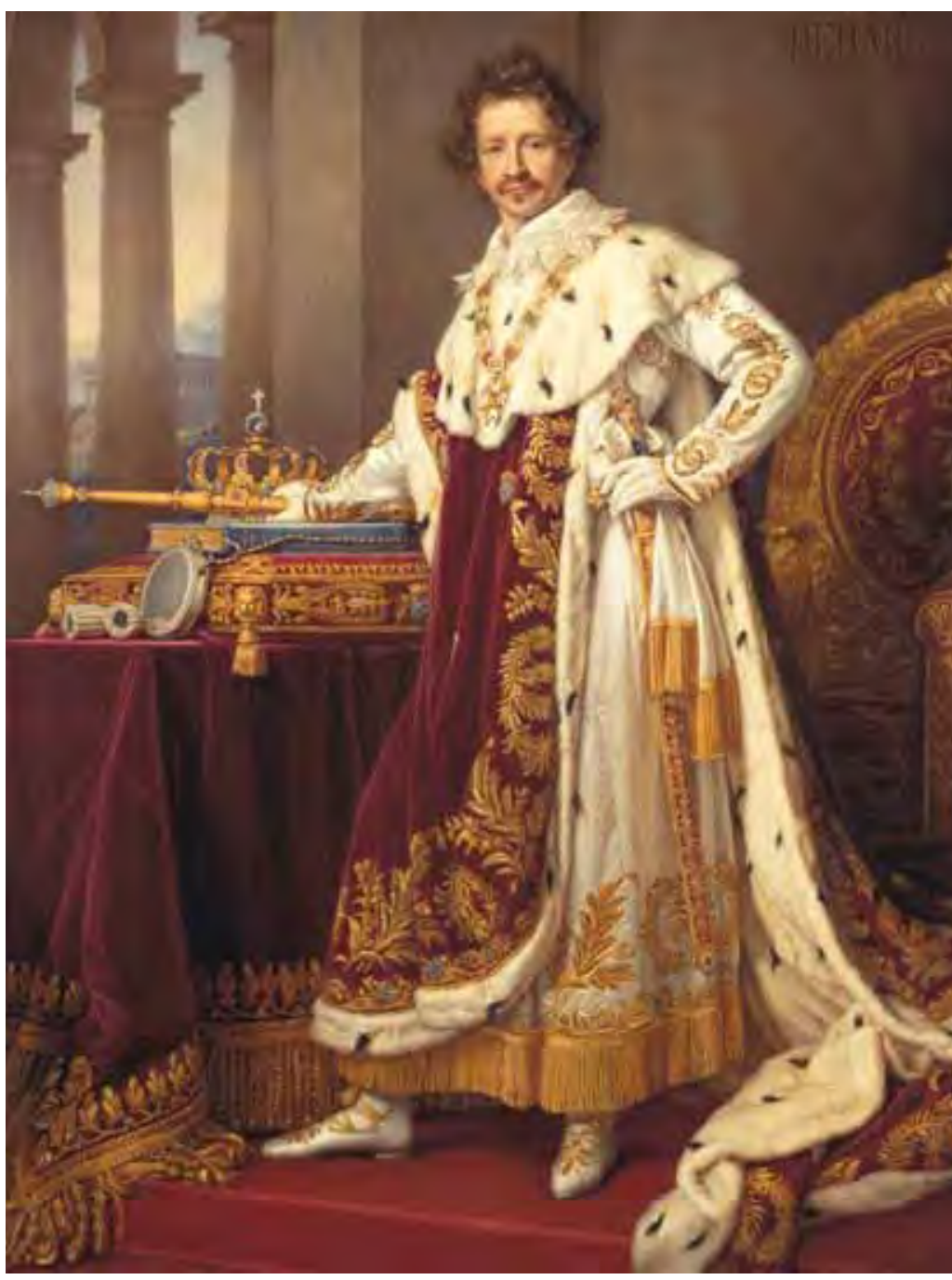




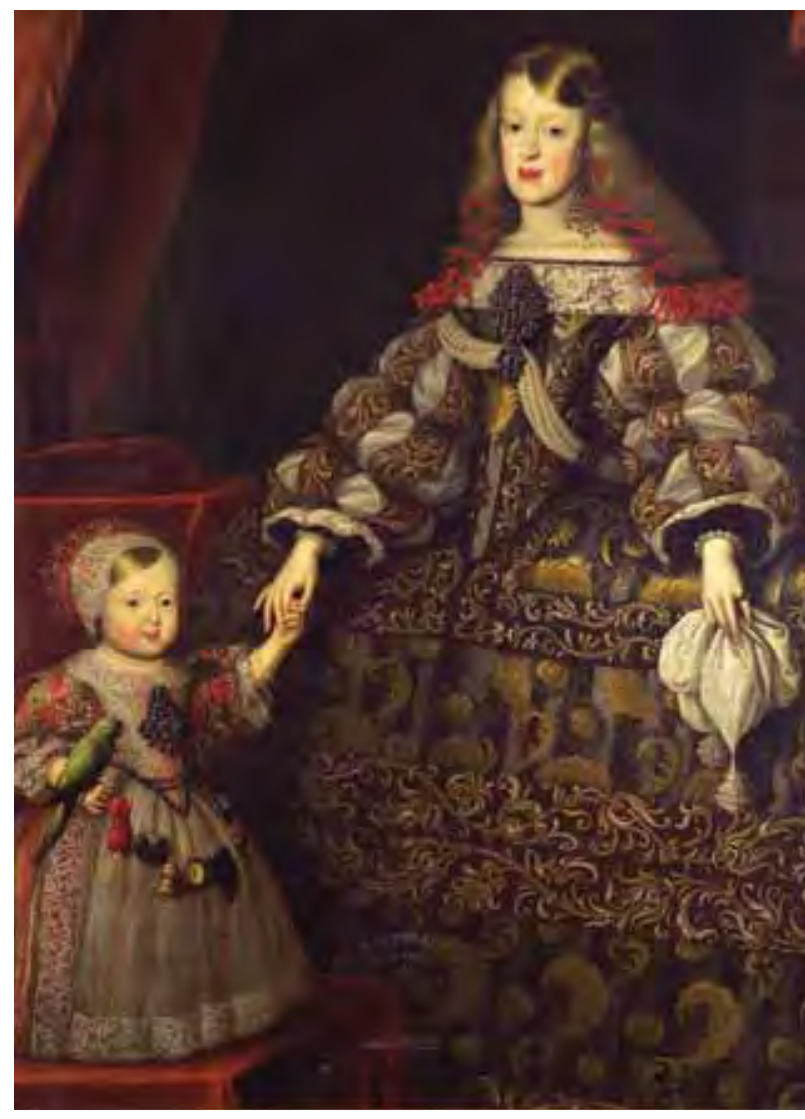

Figure 3. Empress Margarita Teresa of Austria and her daughter Maria Antonia are shown here in this painting attributed to Jan Thomas at the end of the 17th century. Courtesy of the Kunsthistorisches Museum, Vienna.

(LMU) of Munich. (Interestingly, our inquiry at the LMU library in 2006 revealed that Klaus Schneider never completed his doctoral thesis, at least not at LMU or any other German university [see, e.g., Jahresverzeichnis der Deutschen Hochschulschriften, 1960-1970]. During 2006 and 2007, one of the authors [JE] conducted exhaustive efforts to locate Schnei der and de Smet, without success.)

After investigations in the state archives of Bavaria and Austria during September and October of 1961, Schneider traveled to Spain early in 1962 to begin research in an unidentified Madrid archive (de Smet, 1963). Here, he said, he found the first mention of the Wittelsbach Blue "as early as 1664," when King Philip IV (1605-1665) of the Spanish line of the House of Hapsburg, "ordered the treasurer to gather a dowry for his daughter," Infanta M argarita Teresa (1651-1673; figure 3), "from new acquisitions of precious stones from India and Portugal. . . . It included a large blue diamond" (de Smet, 1963, p. 16). According to Schneider, he could find no addi- tional information on the Wittel sbach Blue in Madrid, al legedly because "in the bloody years of the Spanish Civil War (1936-1939) the last existing documents were undoubtedly lost with the destruction of the Madrid archives" (de Smet, 1963, p. 17).

One of the authors (JE) visited Spain in N ovember and December 2007 to seek some archival basis for Schneider's statements. These investigations were performed with the support of five Spanish archivists in the General Archive of the Royal Palace in Madrid (which had no record of Schneider's visit in 1962), in the Archivo General (General Archive) of Simancas, and in the Archivo de la Real Chancilleria (Archive of the Royal Chancery) of Valladolid. No documents could be found to support the contention that Philip's treasurer had purchased a large blue diamond-or other stones from India and Portugal - “as early as 1664." In addition, the archivists were unaware of any records being lost during the Spanish Civil War.

Our 2007 research also reviewed the invoices of the silver- and goldsmiths of the Spanish Court in the General Archive of the Royal Palace in Madrid from 1660 to 1669 for any mention of a large blue diamond, without success. Similarly, the invoices of court treasurers Baltasar Molinet, Antonio de León, and Agustín Spinola for 1660-1669, stored in the Valladolid archive, have no mention of a great blue diamond. One document in particular (found in file number 1816-19) seems to rebut de Smet's contentions. This record dealt with M argarita Teresa's trip to Vienna in 1666 to prepare for her marriage to Emperor Leopold I (Widorn, 1960). The document includes several quotes from goldsmith Luis de Saual ca, who had set diamonds for M argarita Teresa's mother, Queen Maria Anna (1634-96), and who would likely have been commissioned to set a stone such as the Wittelsbach Blue (J. Menéndez Trigos, pers. comm., 2007). Again, however, there is no mention whatsoever of such a diamond. Therefore, Schneider's statements (de Smet, 1963) dealing with Spanish origins of the Wittel sbach Blue must be considered unsubstantiated. The only mention we could find of such a diamond as part of the dowry was in statements made by $M$ argarita Teresa after she had reached Austria.

Vienna Margarita Teresa married her uncle, Emperor Leopold I (1640-1705), in Vienna in 1667 (Widorn, 1960). Figure 3 shows the young Empress with her daughter M aria Antonia three years after the marriage. The marriage contract, dated December 18, 
1663, and currently stored in the Austrian State Archive in Vienna (Marriage contract ... , 1663), contains no mention of a large blue diamond, so the stone likely was not acquired before this date. In 1673, six years after the marriage, Margarita Teresa died. In her testamentary bequest (figure 4), she stated that her daughter, Maria Antonia, was her sole heiress (Widorn, 1960), with one exception: a precious ornament, which she had brought from Spain, was left to Leopold: "a great breast ornament with a great diamond in the midst." Though the blue color is not mentioned, this diamond was most likely the future Wittelsbach Blue: No other large diamond is known to have been possessed by Margarita Teresa, and the court officials at the time would not necessarily have recorded the diamond's color (I. Aguirre, pers. comm., 2008; G. Gonsa, pers. comm., 2008).

Schneider claimed that, on Leopold's marriage to his third wife, Eleonora Magdalena, in 1676 (after the death of his second wife, Archduchess Claudia Felicitas, heiress of Tirol, that same year), he "was so enchanted by her beauty" that he gave the Empress "all the jewelry which he had inherited" from Margarita Teresa (de Smet, 1963, p. 18). Schneider also suggested (de Smet, 1963) that Empress Eleonora Magdalena gave the Wittelsbach Blue by testamentary bequest to her granddaughter, Archduchess Maria Amalia (1701-1756); he based this on docu-

Figure 4. The Testamentary Bequest of Margarita Teresa, dated March 23, 1673, appears to leave the Wittelsbach Blue to her husband Emperor Leopold I. The document reads, "In an Indian writing box. No 1. An ornament of diamonds from her Maj., the Empress brought from Spain; with thick and thin stones with some rhombs; this consists of the following pieces. A great breast ornament with a great diamond in the midst." The color of the diamond is not mentioned. Courtesy of the Austrian State Archives, Vienna, HHStA FUK 1745, 1 and 2.

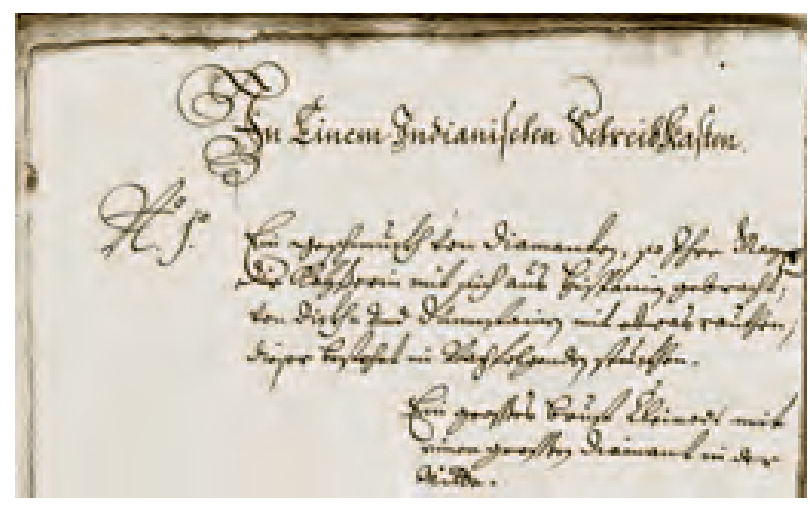

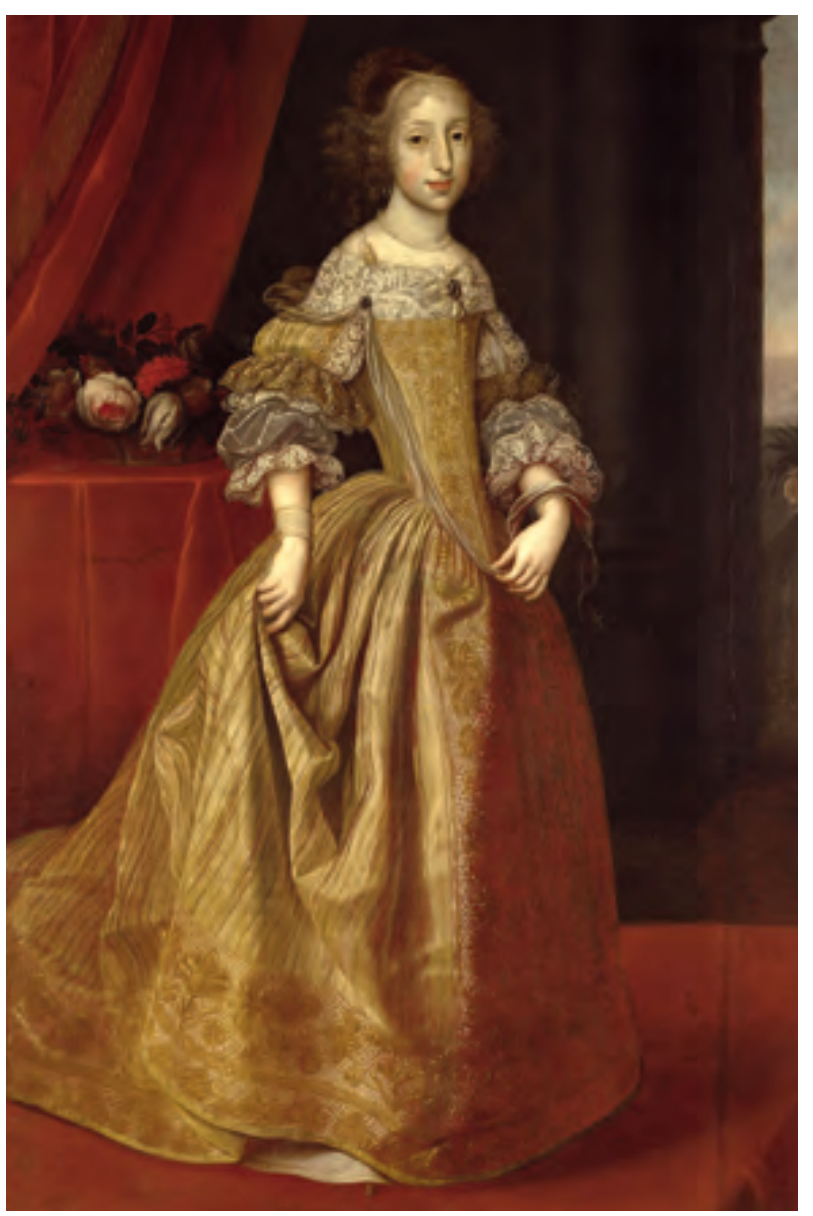

Figure 5. Archduchess Maria Antonia (seen in figure 3 as a toddler) is shown here at the age of 15. She married Bavarian Elector Max Emanuel in 1685, but was not happy with her husband and returned to Vienna in 1692. Painting by Benjamin von Block, 1684; courtesy of the Kunsthistorisches Museum, Vienna.

ments relating to the "Trousseau of Archduchess Maria Amalia." However, investigations in the Austrian State Archive between August 2006 and July 2008 failed to uncover any records supporting Schneider's claims.

Nor does Empress Eleonora Magdalena's testamentary bequest, written between 1711 and 1720, make any mention of leaving the Wittelsbach Blue to Maria Amalia. During her lifetime, Eleonora Magdalena distributed her jewels to her daughters and also one piece to her son Joseph (Maria Amalia's father), who had succeeded Leopold as Emperor in 1705, but she did not itemize gifts for her granddaughters. She left such decisions to her heirs. However, other documents in the Austrian State Archives may lead to a new explanation for the transfer of the Wittelsbach Blue to Maria Amalia.

Archduchess Maria Antonia (figures 3 and 5), 


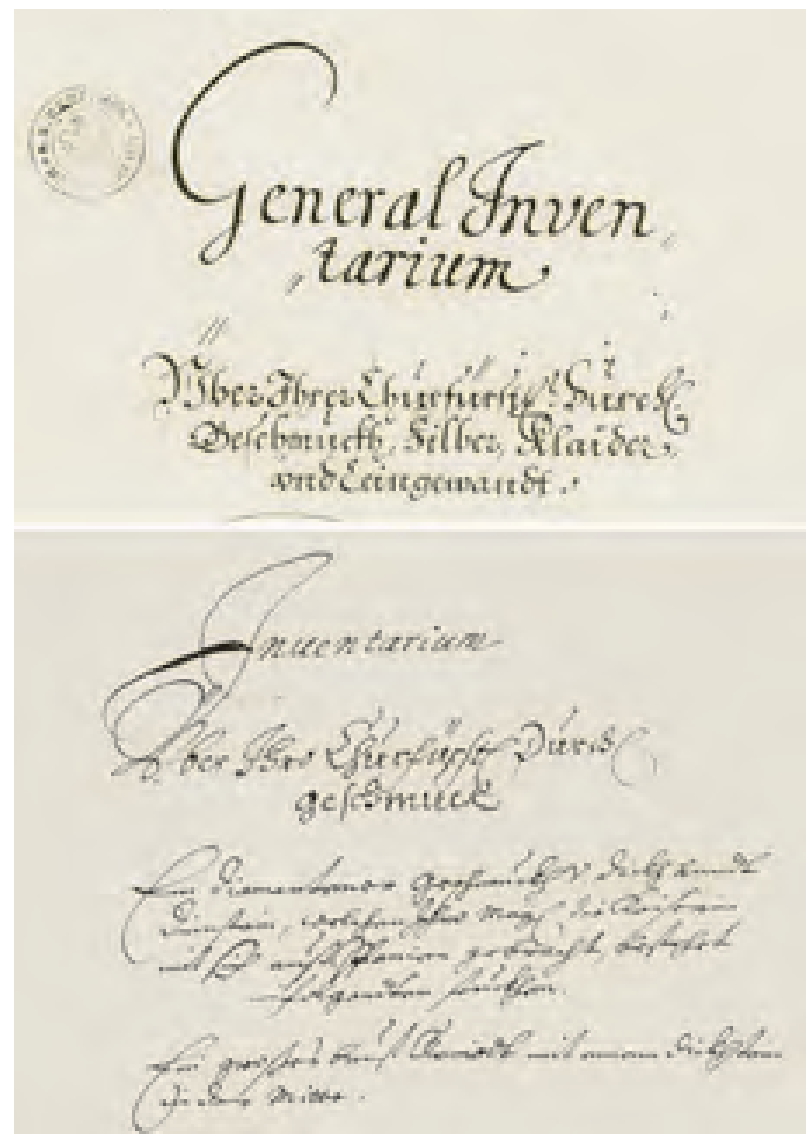

Figure 6. These portions of the General Inventory of Maria Antonia, dated September 22, 1685, indicate that she, too, owned a large diamond but with no mention of the color. They read: "General inventory of her Duchess Highness's Jewelry, Silver, Clothing and Silk garments" (top); and (bottom) "Inventory of her Duchess Highness's jewelry. A diamond jewel of thick and thin stones, which by her Maj. the Empress was brought from Spain, consists of the following pieces. A great breast trinket with a thick stone in the midst." Note the similarity to the description in figure 4. Courtesy of the Austrian State Archives, Vienna, HHStA FUK 1777.

daughter of Margarita Teresa and Leopold, married Bavarian Elector Maximilian II Emanuel Wittelsbach (1662-1726) in July 1685. But it was not a happy marriage, and in early 1692, her husband left Munich to become governor of the Spanish Netherlands in the midst of the Nine Years War (1688-1697) and she returned to Vienna. According to Maria Antonia's "General Inventarium" (General Inventory ... , 1685; figure 6), prepared at the time of her marriage, she then possessed all the jewelry that her mother had brought from Spain in 1667 as her dowry. This 1685 document listed the large ornament with "a thick stone in the midst," using nearly identical language as in her mother's 1673 bequest (figure 4), though still with no mention of the blue color. Although this ornament, again certainly the future Wittelsbach Blue, had been left to Leopold by Margarita Teresa, it seems clear that he passed it to his daughter for her dowry rather than giving it to Eleonora Magdalena as Schneider suggested.

This is further supported by Maria Antonia's testamentary bequest of 1692 (figure 7), which stated that the gold jewelry her mother brought from Spain should stay at the Bavarian court. However, by the time of her death in December of that year, the "Bavarian court" no longer existed as such-Maximilian II Emanuel had by then moved his household to Brussels. Though he returned briefly in 1701, the War of the Spanish Succession, which began that year (and in which Bavaria and Austria fought on opposing sides), would largely keep him away from Munich until the Treaty of Utrecht in 1713. During all this time, Maria Antonia's jewelry remained at the

Figure 7. Maria Antonia's Testamentary Bequest, dated December 12, 1692, also indicates that she inherited some of the jewelry that her mother brought from Spain. It reads: "Yet I procure in memory of my beloved husband the diamond ornaments and the pearls around the neck and hands, which my beloved had given to me after the promise; then thirdly the Spanish ornaments set in gold that have to stay at all times at the Bavarian court and should never be disposed." Courtesy of the Austrian State Archives, Vienna, HHStA FUK 1793/1-4.

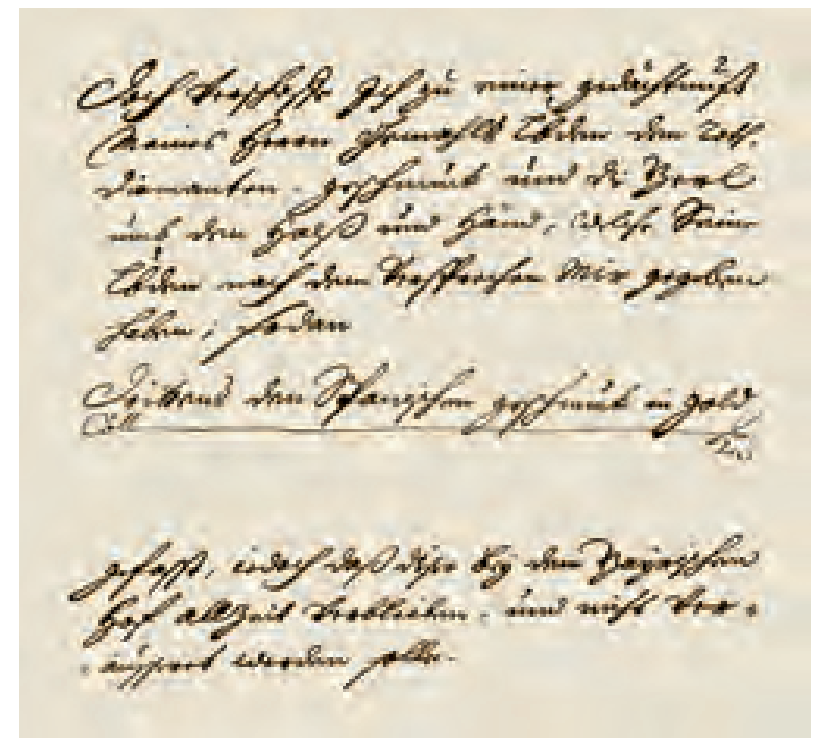




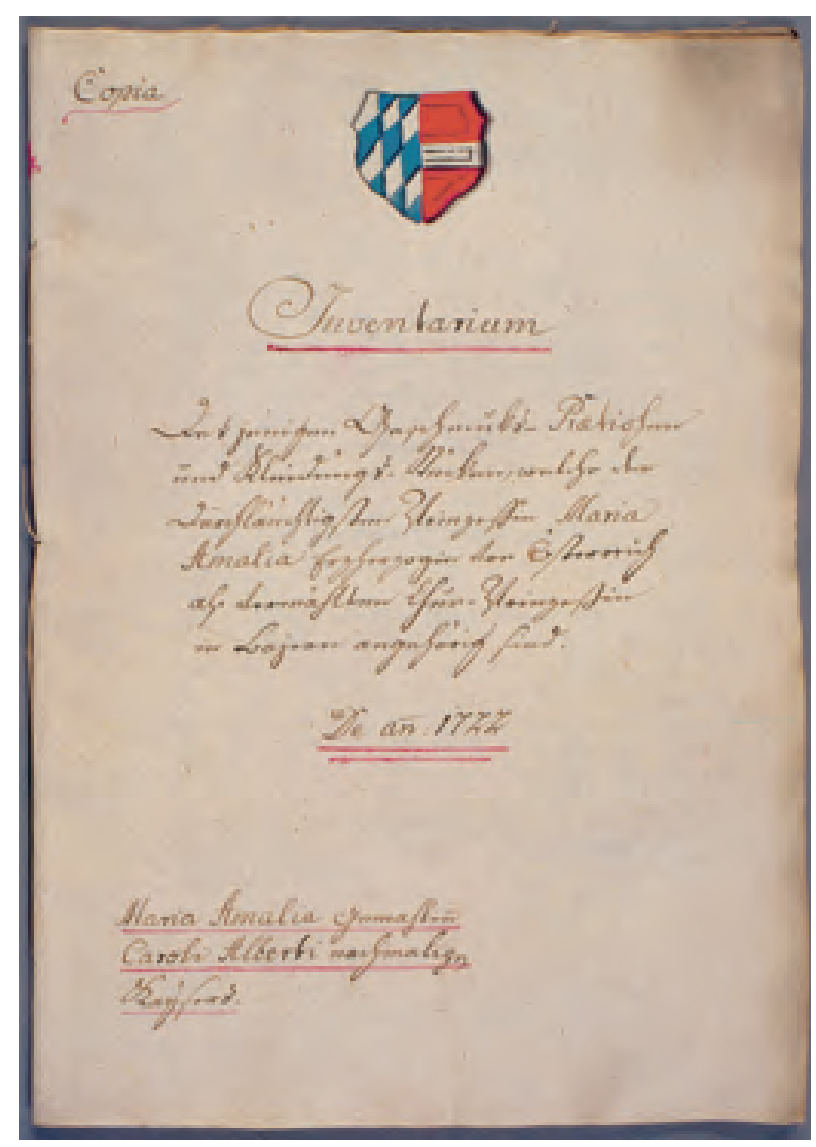

Hapsburg court in Vienna, where it had been at her death, effectively under Emperor Joseph's control. Thus, these documents may explain why the future Wittelsbach Blue became part of Maria Amalia's dowry in 1722, when she, Emperor Joseph's second daughter, married Bavarian Crown Prince Charles Albert (1697-1745).

\section{CROWN JEWEL OF BAVARIA}

Munich. Charles Albert was the son of Maximilian II Emanuel and his second wife, Princess Therese Kunigunde Sobieska. In the inventory of the marriage contract (figure 8), it was agreed that Maria Amalia would bring from Vienna to Munich "gems, jewels, and ornaments," and that inventory documented for the first time "a large blue brilliant, encircled with small brilliants." The official bridal portrait of Maria Amalia, painted in 1722 by Frans van Stampart (Glaser, 1976) and currently exhibited at Castle Hämelschenburg in Emmerthal, LowerSaxony, shows Maria Amalia wearing a hair ornament set with a blue diamond that is clearly identifiable as the Wittelsbach Blue (figure 9). This painting is the oldest visual record of the diamond.

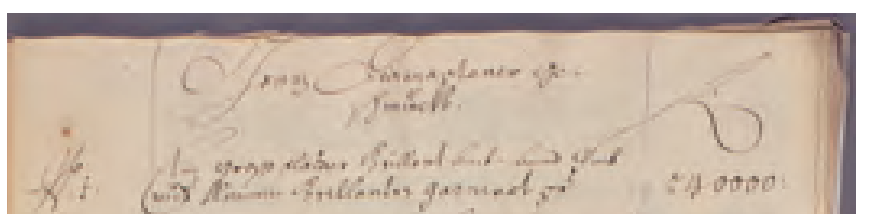

Figure 8. Inventory of the marriage contract between Maria Amalia and Crown Prince Charles Albert of Bavaria, dated 1722. The top of the contract shows a merger of the heraldic emblems of the Houses of Wittelsbach (blue and white) and Hapsburg (red and white). The cover (left) reads in part: "Inventory of the pieces of precious jewelry and clothes which belong to Her Highness Princess Maria Amalia, Archduchess of Austria as married Princess of Bavaria." Above is the entry for the Wittelsbach Blue, reading "Whole diamond ornaments. No. 1: A large blue brilliant, encircled with small brilliants, price 240,000 guilders." Courtesy of the Bavarian Secret House Archives.

Figure 9. In what is believed to be the oldest painting of the Wittelsbach Blue, Maria Amalia's bridal portrait shows the large blue diamond as the centerpiece in her hair ornament. Detail from a painting by Frans van Stampart, 1722; courtesy of Lippold von Klencke, Castle Hämelschenburg.

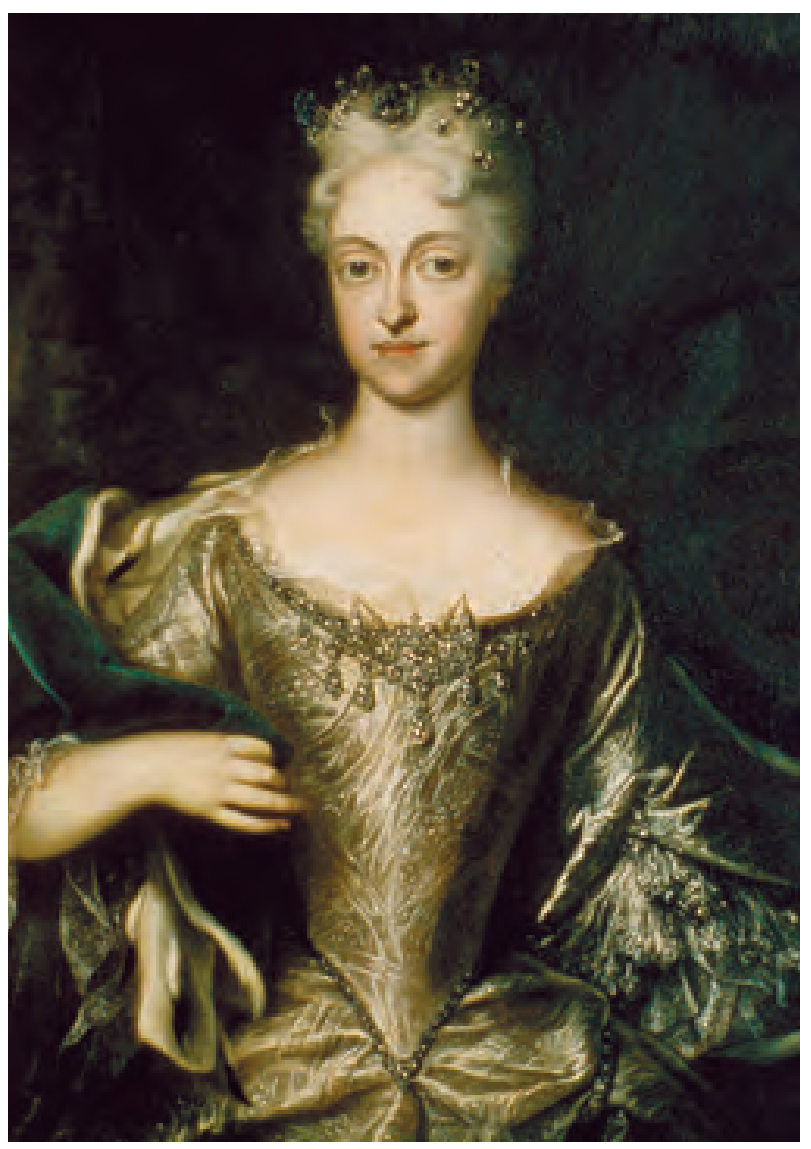




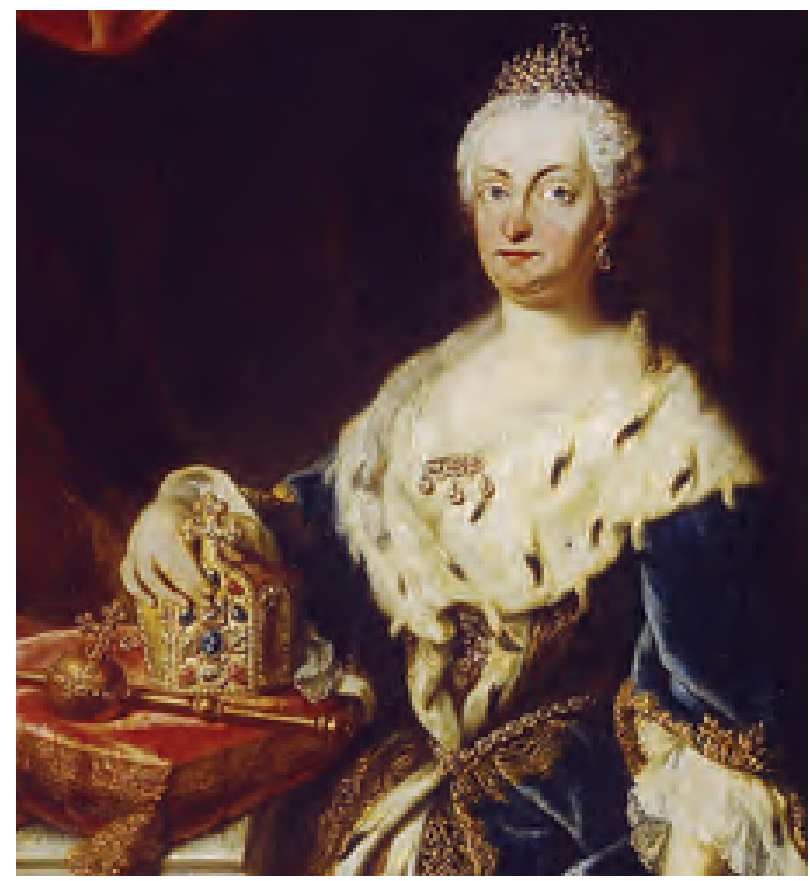

Figure 10. After her accession as empress in 1742 , Maria Amalia wore the Wittelsbach Blue mounted in her crown (on the table to her right). This detail is from a picture painted in 1766, 10 years after her death. From the atelier of Georges Desmarées; courtesy of the Bavarian Palace Department.

After the 1742 coronation of her husband, Emperor Charles VII, now-Empress Maria Amalia wore the Wittelsbach Blue in a crown made to resemble the Ottonian imperial crown (Ottomeyer, 1979; figure 10; the Ottonian dynasty was a line of Holy Roman emperors during the 10th and 11th centuries).

Maria Amalia died in 1756 and in 1761 her son, Elector Maximilian III Joseph (1727-1777), had the Wittelsbach Blue mounted in a badge of the Order of the Golden Fleece, surrounded by large white and yellow diamonds (Schatzkammer der Münchner Residenz, 1937; Brunner, 1970, 1977; figure 11). This badge is currently displayed in the Treasury of the Munich Residence, though with the Wittelsbach Blue replaced by a glass imitation (Ottomeyer, 1979). A January 1774 inventory of all jewels stored in the Munich Treasury described the "Carat 36" Wittelsbach Blue as the most precious gem in the collection, with a value of 300,000 guilders (see the $G \uplus$ ) G Data Depository at www.gia.edu/gemsandgemology).

In January 1806, the kingdom of Bavaria was founded with Maximilian I Joseph as its first king. The new royal Bavarian crown (figure 12) prominently featured the Wittelsbach Blue in the orb under the cross, representing the heraldic blue color of the House of Wittelsbach. It occupied this unique position from 1807 to 1931 .

European crowns typically have a main stone that exceeds all other personal possessions of the ruler in size, color, and value. The Bavarian crown was a state symbol of a constitutional monarchy, and its legal possession was an outward sign of the legitimacy of the king. In Bavaria, the crown and other regalia, such as the sceptre, sword, orb, and the like, served as symbols of the sovereignty of the

Figure 11. Maria Amalia's son, Elector Maximilian III Joseph, had the Wittelsbach Blue set in a badge of the Order of the Golden Fleece in 1761. The blue stone in this figure is a glass imitation. Altogether, 700 diamonds were used in the setting (many of which are small or not visible here). Photo by J. Evers.

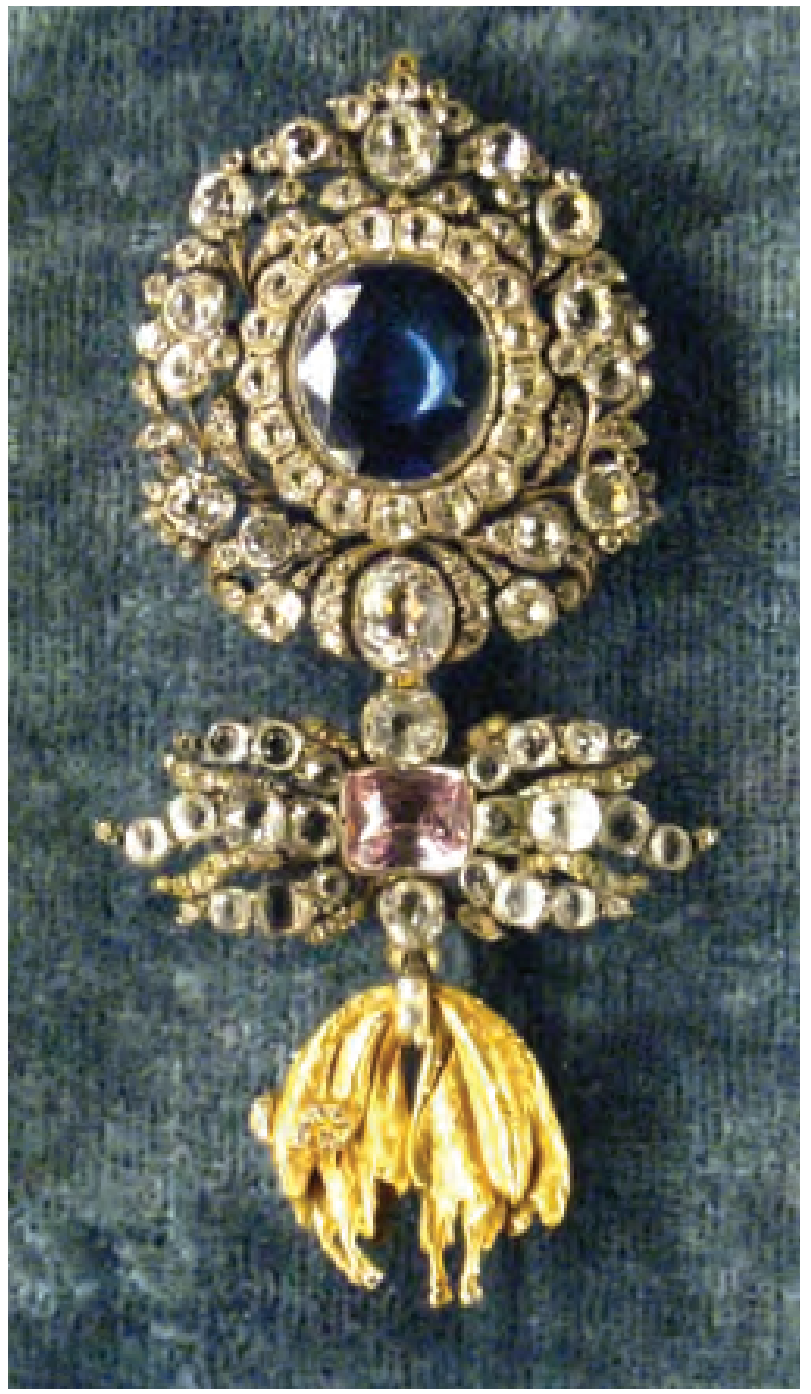


new kingdom during the opening of parliament, the oath of each new King of Bavaria, and other state ceremonies (unlike the practice in other monarchies, the Bavarian crown was not used in coronations or worn by the king). Thus, the jewel on the top of the crown had a meaning beyond its material existence (Puhle, 2006).

The crown was designed in 1806 by Charles Percier, a famous Paris architect and designer for Emperor Napoleon I. Actual construction was by goldsmith Martin-Guillaume Biennais and his craftsmen. The jeweler Borgnis in Frankfurt served as an intermediary to match existing gems in the treasury with new acquisitions to complete the ring of pearls and the settings of various secondary stones (Ottomeyer, 1979; Erichsen and Heinemann, 2006).

The Munich Residence was the city palace of the Bavarian dukes, electors, kings, and emperors from 1508 to 1918. The Treasury of the Munich Residence, located on the ground floor in the eastern part of the Royal Palace (figure 13), is among the foremost of such collections in Europe (Heym, 1999). Until 1931, the most precious gem stored here was the Wittelsbach Blue. In a general bill ("Generalrechnung") from 1807, the Wittelsbach Blue was appraised at 300,000 florins, as much as all other royal ornaments combined (Ottomeyer, 1979).

\section{DISAPPEARANCE AND REDISCOVERY}

London. In 1918, at the end of the First World War, the Kingdom of Bavaria was replaced by the democratic Free State of Bavaria. After years of difficult negotiations, a contract was arranged in 1923 between the House of Wittelsbach and the Wittelsbach Equity Foundation (WAF). All former properties of the House of Wittelsbach, including the inventory of the Treasury of the Munich Residence, were transferred to the WAF to be displayed in public museums. In an appendix, it was stated that the sale of any property belonging to the WAF required the approval of the Bavarian state government. In 1931, the House of Wittelsbach and its head, Crown Prince Rupprecht, were faced with grave financial problems ("Verkauf . . .," 1931), so much so that the WAF decided to sell the Wittelsbach Blue and various other jewels through the auction house of Christie, Manson \& Woods (later Christie's) in London (Christie, Manson \& Woods, 1931). The Bavarian State Government, under minister president Dr. Heinrich Held, gave the required export permission for the Wittelsbach Blue. However, at

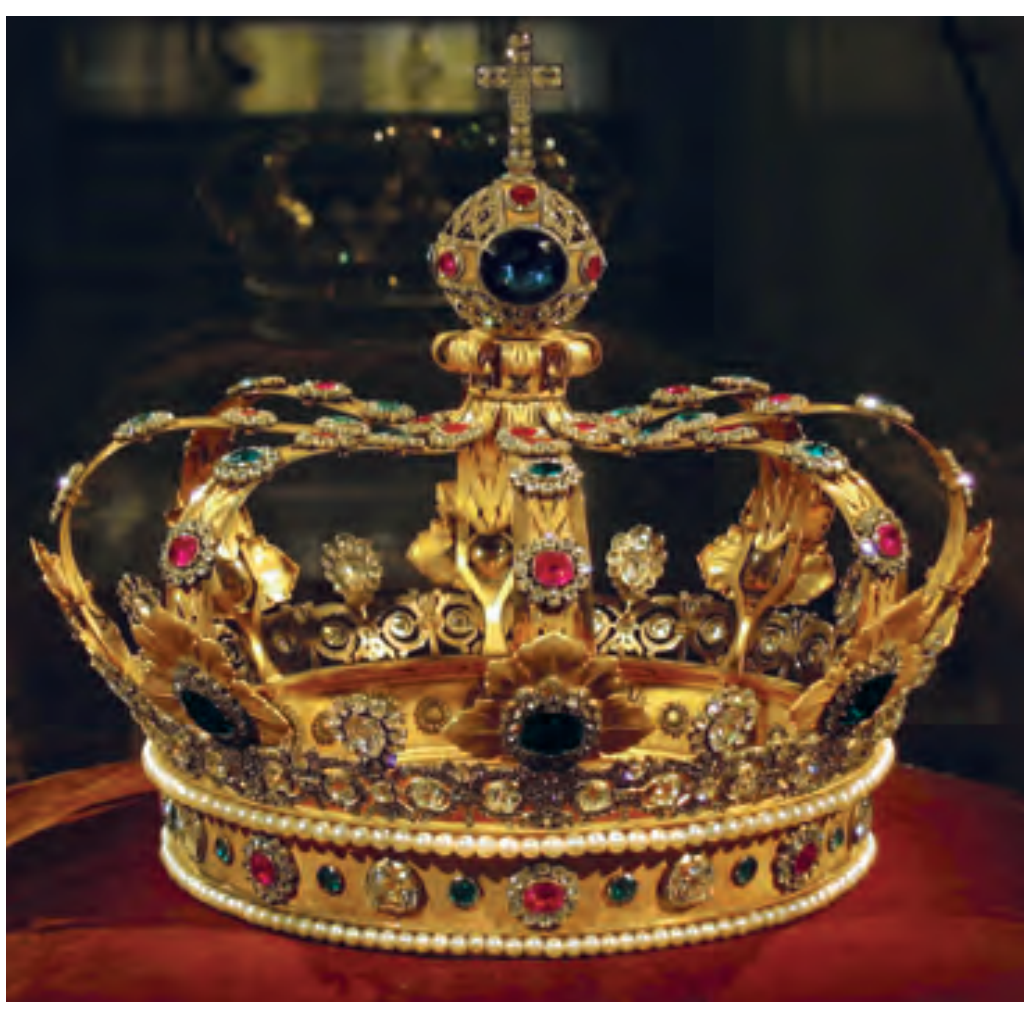

Figure 12. From 1807 to 1931, following the establishment of the Kingdom of Bavaria by Maximilian I Joseph in 1806, the Wittelsbach Blue sat at the top of the royal Bavarian crown. As with the badge in figure 11, it has since been replaced by an imitation made of blue glass. Photo by J. Evers.

the London auction on December 21, 1931 (figure 14), bidding failed to reach the reserve price, and the Wittelsbach Blue was not sold (Bruton, 1981). From the day of the auction until 1961, the whereabouts of the diamond were not publicly known.

Figure 13. The Royal Palace of the Munich Residence was built over 10 years, from 1823 to 1832. The Treasury of the Munich Residence is on the first/ground floor, to the right of the entrance as one goes into the building. It was home to the Wittelsbach Blue during most of the 19th and early 20th centuries. Photo by J. Evers.

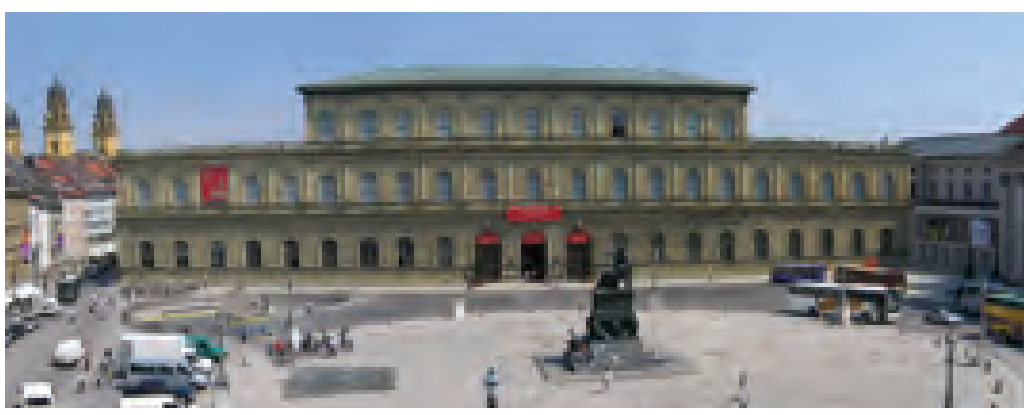


Antwerp, Brussels, and Bruges. Acting in secret, the WAF sold the Wittelsbach Blue in Antwerp in 1951 to a merchant specializing in jewels and ornaments (Kuballa, 1964; Biehn, 1965). Baron Teuchert, speaking for the administration of the WAF, later stated that they did not know the name of this buyer because he was represented by an agent ("Der Blaue Wittelsbacher ... ," 1964). Later in 1951, the Wittelsbach Blue was resold to Antwerp diamantaire Romi Goldmuntz (Kuballa, 1964; figure 15), one of the world's most prominent diamond dealers (de Smet,1963; "Er rührte ...," 1972; Laureys, 2006).

Recently, Dr. Gerhard Immler, director of the Bavarian Secret House Archives, shared with one of the authors (JE) his research into the sales of precious art and gems by the WAF in the early 1950s. At the time, the WAF needed funds to repair damage to their properties that was sustained during World War II. The most direct method for obtaining these funds was by selling art in the WAF's collection. The responsible ministries and their leading secretaries, as well as the Bavarian minister president, supported the decision (G. Immler, pers. comm., 2006).

However, the financial situation of the WAF in the 1950s, as judged by statements made by mem-

Figure 14. In 1931, the Wittelsbachs were forced to put the Wittelsbach Blue (apparently once again mounted in the Golden Fleece ornament in figure 11) and numerous other items of jewelry up for auction. Shown here is the diamond's entry in the auction catalogue; it did not sell. Note that the carat weight as given here is incorrect.

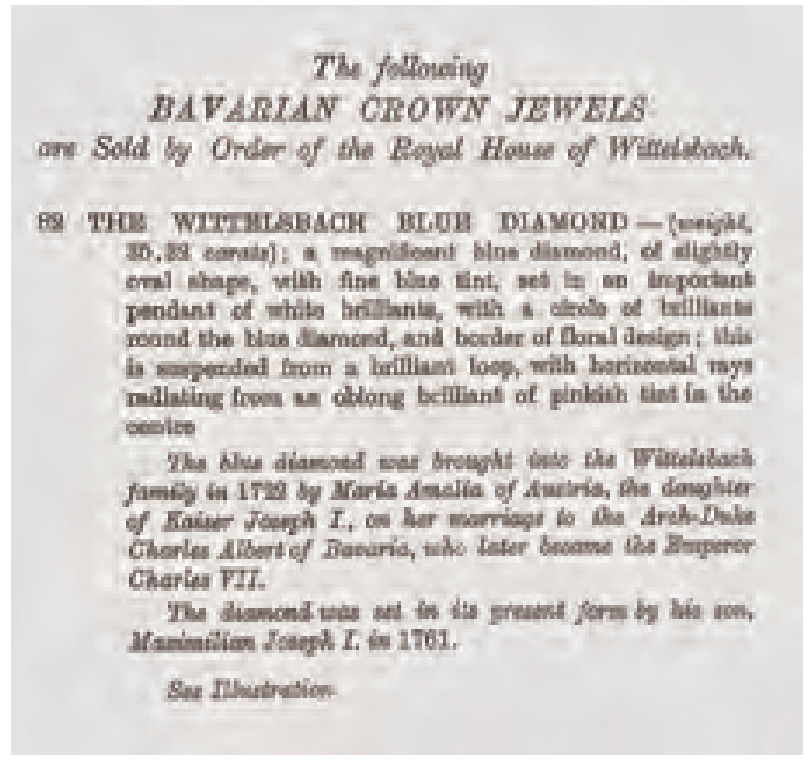

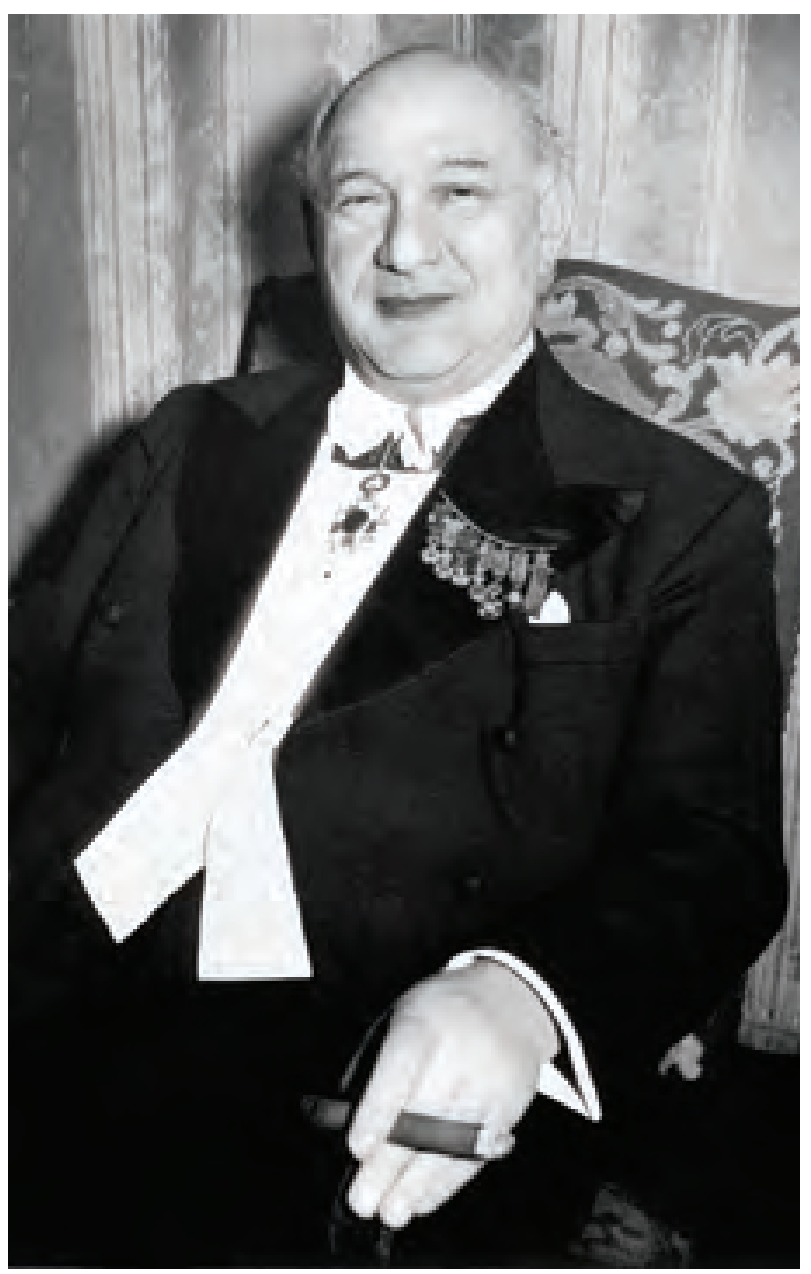

Figure 15. Romi Benjamin Goldmuntz (1882-1960) was one of the greatest diamond dealers in the world. In 1951, he purchased the Wittelsbach Blue in Antwerp, after it was sold in secret that year by the WAF. Photo by Beurs van Diamanthandel.

bers of the House of Wittelsbach during a court case in 1962 ("Wer hat denn ...," 1962), do not seem to bear out a dire need to sell the diamond. Then, the funds of the WAF were estimated to be DM 300-500 million. The value of the Wittelsbach Blue in 1951, based on events during the 1960s (see below) was probably about DM 1 million. Compared to the estimate of the WAF's total funds, an additional DM 1 million gained by selling the Wittelsbach Blue-the most precious piece of the Munich crown jewels-seems to be a very small improvement, even in a strained financial situation.

From April 17 to October 19, 1958, the Universal and International Exhibition (EXPO'58) was held in Brussels. Forty-seven Belgian jewelers, including Romi Goldmuntz and J. Komkommer \& Son, displayed their gems at the Belgian Diamond 
Industry pavilion (Exposition U niverselle et Internationale de Bruxelles, 1958, 1961; Official Guide...," 1958). There, among other gems, Goldmuntz displayed the Wittel sbach Blue-without giving its name or origin. N or was it known at the time that Goldmuntz was the owner of the large blue diamond. Further, though the Wittel sbach Blue was one of the largest and most historic blue diamonds in the world, not one of the millions of EXPO visitors-including diamond expert and later purchaser Jozef Komkommer-appeared to recognize it (de Smet, 1963).

After Goldmuntz's death in 1960, his heirs discovered the diamond in his gem collection, thinking it nothing but a large old-mine-cut stone. $\mathrm{N}$ ot knowing the origin of the blue gem, in August 1961 they asked Antwerp jeweler Jozef Komkommer to recut it into a "pear-shape, emeral d-cut or oval" (de Smet, 1963, p.7). However, contrary to de Smet's claims, Komkommer may not at first have realized what they had brought him. In a January 2008 interview with Jan Walgrave, former di rector of the Provincial Diamond Museum Antwerp, Komkommer's son Jacques claimed that he initially suggested a probable historic origin for the blue gem (). Walgrave, pers. comm., 2008). Father and son compared characteristic data for historic diamonds in The Diamond Dictionary (Copeland et al., 1960), and in doing so quickly identified the unknown blue diamond as the missing Wittelsbach Blue. Together with some closely associated jewelers, Jozef Komkommer purchased the Wittel sbach Blue on August 28, 1961 (Burgerwelzijn, 1962; V. De Boi, pers. comm., 2007).

Soon thereafter, Komkommer contacted the Treasury of the Munich Residence-including Duke Albrecht of Bavaria, then head of the House of Wittel sbach, and Baron Teuchert of the WAFoffering to sell back the diamond. We do not know the price he quoted, but it has been reported as either DM 1.5 million ( $\$ 375,000$; “Der Blaue Wittel sbacher . . .," 1964) or DM 2 million ("Wer hat denn ...," 1962). Whatever the price, Duke Albrecht refused the offer. Baron Teuchert, for his part, called the Wittelsbach Blue an "unproductive asset" not worth buying back ("Der Blaue Wittelsbacher... ,"1964). He also then revealed where the diamond had been during 1931-1951: back in the WAF's safe in Munich.

Luceme, Hamburg and Düsseldorf. Spurned by the Wittelsbachs, Komkommer sought other buyers.
On August 14, 1963, during the International Lucerne Music Festival, he exhibited the Wittel sbach Blue at the Gübel in jewelry store, then overseen by famed gemologist Dr. Edward Gübelin. At the time, the Wittelsbach Blue was valued at about 2 million Swiss francs or around $\$ 500,000$. Publicity was high: Three local newspapers reported on the event ("Ein berühmter Steinerner ... ., 1963; "De Grote Blauwe Diamant .. . ," 1963; "Der 'Wittel sbacher' in Luzern," 1963). Komkommer had hoped to sell the Wittelsbach Blue to one of the festival guests, but by mid-September had seen no success. However, while the stone was in Lucerne, Dr. Gübel in was able to conduct the first gemological examination of the diamond (see below).

In 1964, Hamburg jewel er Renatus Wilm recognized a chance to sell the Wittelsbach Blue to one of his countrymen (Kuballa, 1964, Biehn, 1965). Some "residual patriotism" led him to fear that this most important historic German gem could "drift to America," as had happened earlier with the Hope diamond. Komkommer and Wilm entered into a contract: Wilm would earn a $\$ 50,000$ finder's fee if he sold the Wittelsbach Blue by January 31, 1965, but Komkommer would get the same amount of money from Wilm should Wilm be unsuccessful (Kuballa, 1964; Biehn, 1965). To this end, Wilm exhibited the Wittelsbach Blue in his jewelry shops in Düsseldorf and Hamburg during October.

Wilm's efforts saw more success than those of Komkommer. At the end of 1964, he sold the Wittel sbach Blue and earned his $\$ 50,000$. The name of the buyer was not disclosed.

\section{SOLD TO A PRIVATE PARTY}

Antibes and Zurich. Here, the previously published history of the Wittelsbach Blue (e.g., Gaal, 1977; Bruton, 1981; Balfour, 1997; M orel, 2001) comes to an end, with the fate of the diamond after 1964 largely a mystery. In March 2006, we began our investigations to determine the name of the private purchaser in the digital archives of German newspapers and magazines. Our attention soon focused on Helmut Horten (1909-1987) of Düssel dorf, at one time the owner of one of Germany's largest department-store chains. One of the authors (RD) had first speculated on Horten's identity as the buyer of the Wittelsbach Blue in an article published in a small journal on Palatine topography in 1982 (Dröschel, 1982). 


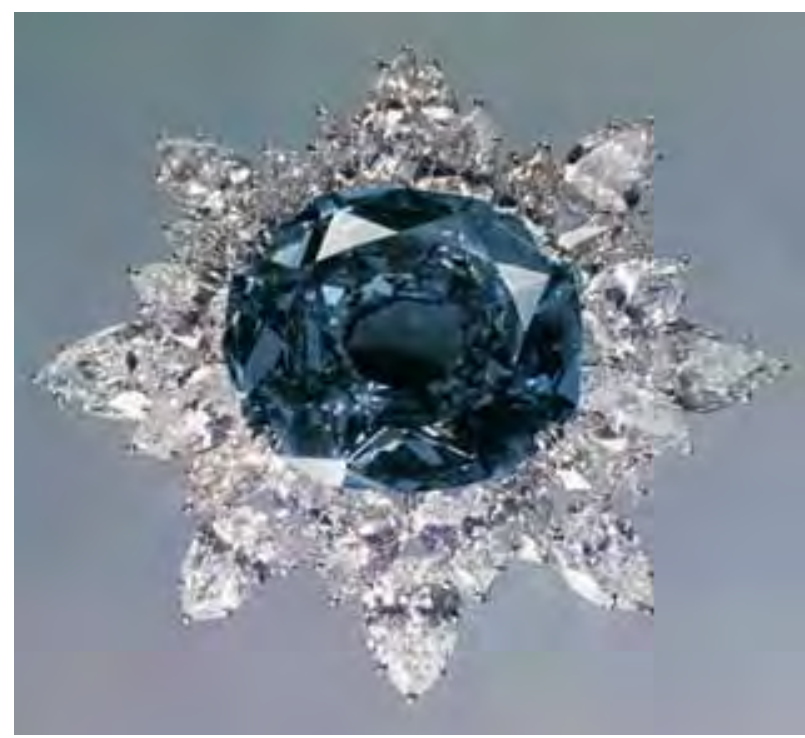

Figure 16. This photo of the Wittelsbach Blue was taken by Ernst Albrecht Heiniger and his wife Jeanne after years spent tracking down the diamond. The mounting was created in the 1960s by Harry Winston and was designed to reduce the visibility of the extremely large cul et, and thus improve the overall appearance of the historic stone. Reprinted by permission of J. Heiniger.

The first reports connecting Horten with an unnamed 35 ct blue diamond were published in 1966. Horten had married in secret that year; his bride was a young secretary from Vienna named Heidi Jelinek, 32 years his junior (Bissinger and Lebeck, 1971a). Reports of the wedding appeared in the Rheinische Post (Diebäcker, 1966) and other publications (Adabei, 1966a,b) on August 3, 1966. Among other salacious details about the party at which Horten celebrated his second marriage, the article reported that Horten had presented his wife with a 35 ct blue diamond as a wedding gift. For Rheinische Post journalist Diebäcker, the article had severe consequences (J. Diebäcker, pers. comm., 2006). Horten withdrew all advertisements for his stores (in the order of DM 1.5 million), demanding that Diebäcker be fired. Fortunately for Diebäcker, the publishers of Rheinische Post refused. (The two other articles-Adabei, 1966a,b-were published pseudonymously.)

A two-part 1971 article in Stern magazine (Bissinger and Lebeck, 1971a,b) provided more details of the Hortens' post-wedding party at Cap d'Antibes, France, which according to Diebäcker featured performances by the famed BlueBell Girls dancing troupe from Las Vegas, a ballet troupe from Tokyo, a dancing group from Oslo, and musicians from
Greece (Diebäcker, 1966). Reportedly, Helmut Horten presented the diamond to Heidi by simply pulling it from his trouser pocket in the midst of this gala. The 240 guests in attendance likely did not realize that the blue gem at the center of this scene was irreplaceable, once part of the Treasury of the Munich Residence.

Other popular journalists were also seeking the diamond. Academy Award-winning Swiss film producer Ernst Albrecht Heiniger (1909-1993; L. Piccolin, pers. comm., 2004) and his wife Jeanne were also avid gem photographers. The Great Book of Jewels (Heiniger and Heiniger, 1974) includes the story of their years-long search for the Wittelsbach Blue in the early 1970s.

The Heinigers had traveled thousands of miles to locate the gem without success. The diamond was nowhere to be found, and the name of the 1964 purchaser "was guarded with utmost secrecy" (Heiniger and Heiniger, 1974). Finally, after three years, they learned by chance that the Wittelsbach Blue was stored in a vault not far from their photo studio in the Zurich Bahnhofstrasse (G. Kling, pers. comm., 2007). Photographing the Wittelsbach Blue requi red lengthy negotiations and a costly insurance policy (Heiniger and Heiniger, 1974). In addition, they were required to sign documents stating that they would never reveal any information about the owner or the stone's location. The photo of the Wittel sbach Blue taken by the Heinigers is shown in figure 16.

A variety of other reports of the blue diamond appeared in German publications over the ensuing decades (e.g., N euhauser, 1971; Zi pser, 1991). Although no other blue diamond of this particular weight has ever been reported, none of these articles identified the stone as the missing Wittel sbach Blue. However, a brief 1979 article discussing the 70th birthday celebration of Helmut Horten (" 70 Jahre $\mathrm{H}$. Horten,") finally confirmed the Hortens' ownership of the historic diamond. The article mentioned that, in 1966, Horten had presented Heidi with one of the greatest diamonds that ever adorned a woman: the famous “Wittelsbach Blue” (figure 17).

In March 2006, 27 years after this article appeared, one of the authors (JE) asked the Welt am Sonntag editor responsible for the 1979 report about its factual basis. He replied that the paper would not have published information on a stone like the Wittelsbach Blue from the private life of a person like Helmut Horten without his specific agreement. 
The authors also contacted Jeanne Heiniger in September 2007 asking her to review the sections of this article dealing with the Hortens' ownership and the Heiningers' photograph of it. She answered by e-mail that "no addendum and no correction" were required (J. Heiniger, pers. comm., 2007). This is the second independent "source" for the Hortens' ownership.

St. Moritz and London. In N ovember 2006, the authors received a report that the elusive Wittelsbach Blue had recently been displayed in a private exhibition at the Bulgari store in St. Moritz,

Figure 17. This brief article in the January 7, 1979 issue of the German national Sunday newspaper Welt am Sonntag, marks Helmut Horten's 70th birthday, and for the first time publicly links Horten and his wife with the Wittelsbach Blue.

\section{Jahre H. Horten}

ws. Zürich

Horten lebt heute in der Schweiz - zusammen mit seiner zweiten Frau Heidi, einer gebürtigen Wienerin. Bevor er sie 1966 heiratete, schenkte er ihr als Zeichen seiner Verehrung einen der größten Diamanten, der je eine Frau zierte: den berühmten „Blauen Wittelsbacher" von 35,3 Karat.

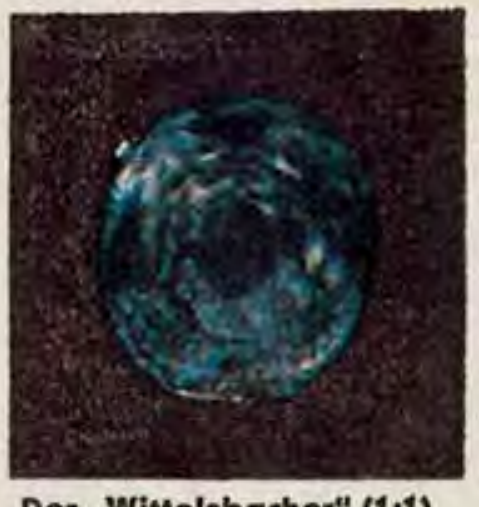

Der „Wittelsbacher" (1:1)
Switzerland. This exhibition and a later one in Vienna were probably the first indications that Heidi Horten planned to sell the Wittel sbach Blue.

In N ovember 2008, Christie's announced that the Wittelsbach Blue would be sold at auction in London on December 10, 2008 (Christie's, 2008a,b; Kratzer and Evers, 2008). This auction was conducted at Christie's headquarters-the same building where the Wittel sbach Blue was unsuccessfully offered nearly 80 years earlier. The winning bid was placed by London jeweler Lawrence Graff, who paid a hammer price of $£ 16,393,250$, or just over $\$ 24.3$ million and $\$ 683,000$ per carat (Christie's, 2008c). This is a record price for any diamond or piece of jewelry at auction. The WAF did not participate in the auction, but the authors have been told that it intends to negotiate with Graff to purchase the diamond (R. Borchard, pers. comm., 2008). However, no decisions in that respect had been made when this article went to press.

\section{GEMOLOGICAL INVESTIGATIONS}

During the short period in 1963 and 1964 between the rediscovery of the Wittelsbach Blue by Jozef Komkommer and its sale to Horten, a few diamond specialists had the opportunity to examine it. In addition to Dr. Gübel in, these included Finnish jeweler and diamond historian Herbert Tillander, who measured the cut, weight, and dimensions (Tillander, 1965). Hamburg jeweler Renatus Wilm, who had sold the Wittelsbach Blue to Horten in 1964, supported Tillander's findings. M ost recently, the Christie's catal ogue in which the diamond appears published a copy of the September 24, 2008, GIA Colored Diamond Grading Report on this stone (Christie's, 2008b, p. 126).

The rough diamond from which the Wittel sbach Blue was cut was probably a flat slab about $9 \mathrm{~mm}$ thick. This can be deduced from the broad proportions of the cut and the extremely large culet. Where the Wittel sbach Blue was cut and polished cannot be stated with certainty, but Paris (M orel, 1988), Lisbon and Venice (Tillander, 1995), and Bruges, Antwerp, and London (Bruton, 1981) have all been proposed in the literature. Jozef Komkommer reported the polish of the Wittel sbach Bl ue as being "uncommonly smooth, smoother than the work of the very best polishers of today" (de Smet, 1963, p. 8). Tillander also reported that the "appearance of this stone is particularly striking because of its unusually fine 


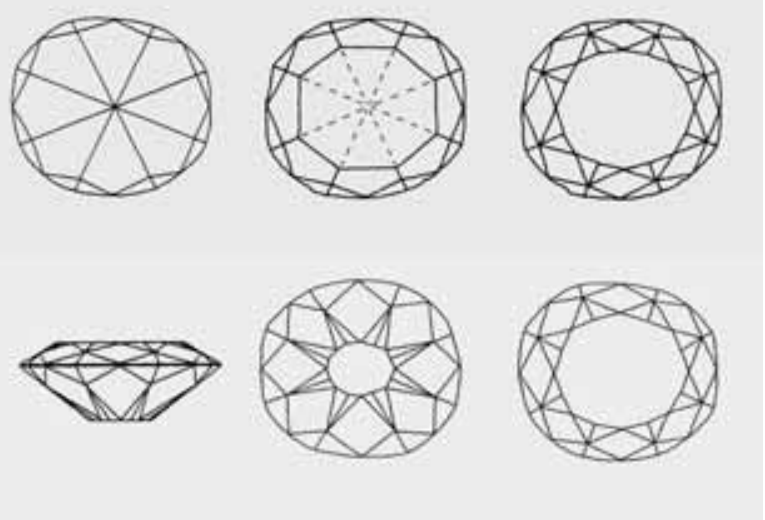

Figure 18. Tillander's sequence of drawings illustrates how the Wittelsbach Blue may have been devel oped from a variant of the pointed star cut (left). At center, the apex is replaced by a large table facet, after which star facets are added around the table (right). The complete facet diagrams are shown along the bottom. From Tillander, 1995.

polish and the absolute flatness of the facet surfaces" (Tillander, 1965).

In the GIA report, the cut of the Wittelsbach Blue is described as a "cushion modified brilliant." Like a modern brilliant cut, it shows excellent eightfold symmetry (figure 18). According to Tillander, it is basically a star cut (figure 18, top left) with its apex replaced by a table facet (figure 18, top center), so that the radially bisected girdle facets remained unchanged. Then, a brilliant cut was superimposed to complete the cut (figure 18, top right; Tillander, 1965). In addition to the main and girdle facets, the Wittel sbach Blue has double pavilion facets-perhaps unique for a historic diamond cut-with eight precisely developed facets around the culet (figure 18, bottom). According to Tillander (1995), it is the earliest known brilliant.

Photos of the stone and the GIA report indicate that over the years the knife-edge girdle was damaged in several places (figure 19). One can only hope that a future owner of the Wittelsbach Blue does not repolish it in order to remove this minor damage, as it would result in a loss of the stone's subtle original substance, identity, and historic form. However, a statement from Graff Diamonds shortly after the December 10 auction indicated that they intended to do just that, with the aim of making the diamond "flawless and a deeper color" (Reyburn, 2008).

As noted, the first gemological characterization of the Wittelsbach Blue as a type IIb diamond was performed in 1963 by Dr. Gübelin ("De Grote
Blauwe Diamant . . .," 1963). Balfour (1987) later reported that Gübelin observed red phosphorescence after exposure of the stone to short-wave ultraviolet radiation. Most blue diamonds display a chalky blue to green phosphorescence; only very rarely, as with the Hope diamond, do they exhibit red or orange-red (King et al., 2003; King et al., 1998). Gübelin also reported "strong semiconductivity" ("Ein berühmter Steinerner... ," 1963; "De Grote Blauwe Diamant . . . ," 1963). In a letter that accompanied the diamond grading report (Christie's, 2008b, p. 124), GIA confirmed that the $35.56 \mathrm{ct}$ diamond was a type IIb with a moderate concentration of boron and that it had "bright and persistent red phosphorescence," similar to that present in the Hope diamond. It is also interesting to note that, like the Hope, the Wittel sbach Blue was color graded Fancy Deep grayish blue. The GIA report gave the clarity grade as $\mathrm{VS}_{2}$ and the color as even. Polish and symmetry were "good," and-as noted by others-the girdle was extremely thin. M easurements reveal ed a $64 \%$ table, extremely large cul et, and $38.8 \%$ total depth.

Figure 19. Over the centuries, the Wittel sbach Blue has sustained a certain amount of damage. The worst is to its knife-edge girdle, which suffered severe chipping over its three centuries of known history. Photo courtesy of Christie's.

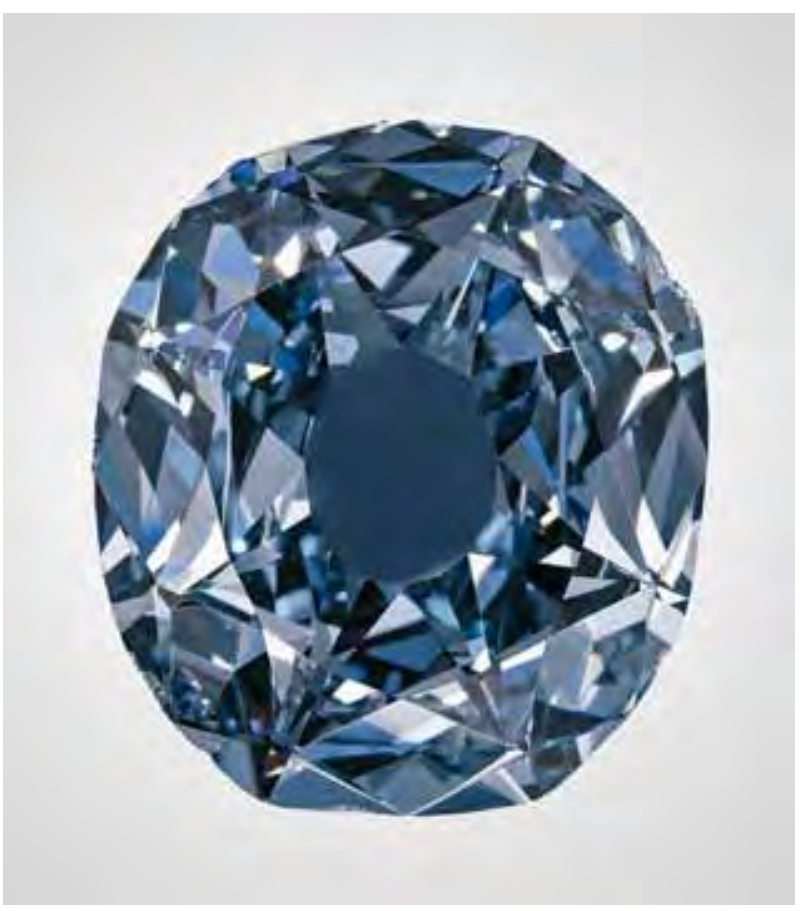




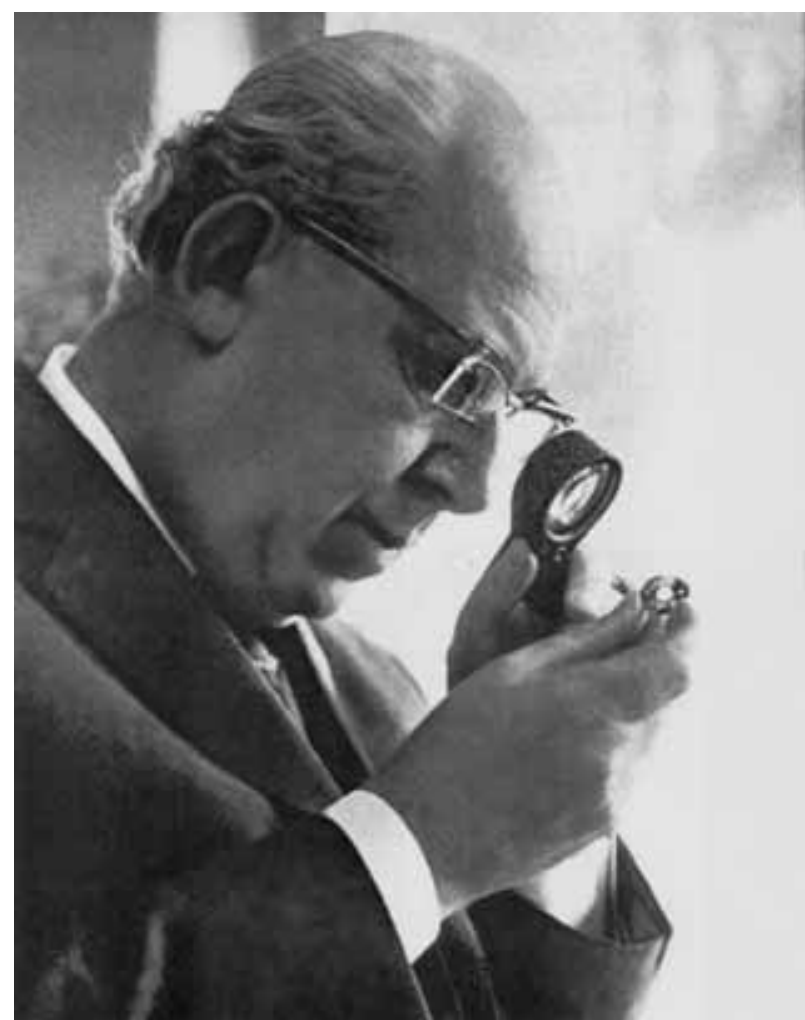

Figure 20. Jozef Komkommer (1911-1980), whose recognition of the Wittel sbach Blue in 1961 (with the help of his son) saved it from recutting, is shown here examining the diamond with a loupe.

\section{CONCLUSON}

Helmut Horten died in Switzerland in November 1987. Heidi Horten, who has no children, is now the richest woman in Austria, with assets of $€ 3.7$ billion ("Special report: The world's billionaires," 2008). Although she can use and increase the possessions of her former husband, she is not allowed to dispose of them in her will (Stern, 1971a; "Der Lotto-Gewinn des Jahres . . .," 1994). This may be the reason why she decided to sell the Wittelsbach Blue, which was her personal property, at the Christie's auction.

During the 30 years between 1931 and 1964, the list of poor decisions dealing with the fate of the Wittel sbach Blue is remarkable. However, one man made the right decision for the Bavarian blue diamond, at the right moment: Jozef Komkommer, who refused to recut the Wittelsbach Blue into a more modern shape and thereby preserved its subtle essence, historical identity, and importance. The photo of Jozef Komkommer examining the Wittel sbach Blue in figure 20 serves as a small monument to a conscientious man.

\section{ABOUT THE AUTHORS}

$M r$. Dröschel is a diamond historian in Idar-Oberstein, Germany. Dr. Evers (eve@cup.uni-muenchen.de) is a professor in the Department of Chemistry and Biochemistry, University of Munich. Dr. Ottomeyer is a professor at Humboldt University, Berlin and director general of the German Historical Museum, Berlin.

\section{ACKNOWLEDGMENTS}

The authors thank the following individuals for assistance in the preparation of this article: Mrs. W. Bartling, Hamburg; Mrs. Dr. H. Bauer, Kronen Zeitung, Vienna; Mrs. Dr. A. Baumeister and Dr. W. Alberg, Stadtmuseum Düsseldorf; Duke Franz of Bavaria, Munich; Manfred Bissinger, Hoffmann und Campe Verlag, Hamburg; Mrs. V. de Boi, Stedelijke Musea, Bruges; Ralf Borchard, Bavarian Radio, Munich; R. Burri, Zurich; S. Conrad, A. Neuhoff, Prof. Dr. T. M. Klapötke, and G. Oehlinger, Ludwig-Maximilian University, Munich; Mrs. K. Dannel, Airport Hamburg GmbH; J . Diebäcker, Duisburg; Dr. R. Dünki, Stadtarchiv Zürich; Mrs. L. Enderli, Fotostiftung Schweiz, Winterthur; Mrs. E. Heise, Neue Pinakothek, Munich; Dr. F. Falk, Schmuckmuseum Pforzheim; Mrs. D. Frost, Staats- und Universitätsbibliothek Bremen; J . Glasner and G. Reiprich, Bayerisches Hauptstaatsarchiv, Munich; Dr. G. Gonsa, Austrian State Archive, Vienna; Dr. S. Heym, Mrs. B. Weis, G. Graml, and J .
B reithoff, Bayerische Verwaltung der staatlichen Schlösser, Gärten und Seen, Munich; Mrs. A. Grüter and Mrs. M. Hug, Zentral- und Hochschulbibliothek, Lucerne; Th. Gübelin, Lucerne; Mrs. J. Gutwein, New York; Dr. O. von Habsburg, Starnberg; K. Hageresch, RotoSmeets, Bielefeld; Mrs. J eanne Heiniger, California; Dr. G. Immler and A. Leipnitz, Geheimes Hausarchiv, Munich; L. von Klencke, Hämelschenburg; Mrs. Dr. G. Kling, Archiv Swiss PTT, Bern; J acques Komkommer, Antwerp; G. Krummenacher, Zürcher Hochschule der Künste, Zurich; Mrs. B. Kunze and B. Hinderer, Axel-Springer-Verlag, Berlin; Dr. E. Laureys, Mortsel, Mrs. L. Overstreet and Mrs. M. Rosen, Smithsonian Institution, Washington D.C.; L. Piccolin, Zurich, Mrs. P. Riekel and Mrs. R. Laukhuf, Hubert Burda Medien, Munich; Dr. K. Schütz, M rs. I. J ung and A. Rührig, Kunsthistorisches Museum, Vienna; H. H. Serges, Serges Verlag, Solingen; T. Snoeren, Het Parool, Amsterdam; Mrs. L. Carillo Carminal, Biblioteca Nacional Madrid; M rs. A. Huete, J . L. H. Elvira, A. A. Zimmerli, Palacio Real, Madrid; Mrs. I. Aguirre, Simancas and J. Menéndez Trigos, Valladolid; Dr. G. Steinhauser, Atom-Institut, Vienna; Mrs. Dr. U. Tillander-Godenhielm, Grankula; J. Walgrave, Provinciaal Diamond Museum, Antwerp; and R. Wolfensberger, Museum für Kommunikation, Bern. This article is dedicated to Prof. Dr. Dr. h.c. Heinrich Nöth, former President of the Bavarian Academy of Science, on the occasion of his 80th birthday. 


\section{RHERENCES}

Adabei (1966a) Hortens heimliche Heirat [Horten's private marriage]. A bendzeitung, August 3.

Adabei (1966b) [no title]. Express, August 3.

Balfour I. (1987) Famous Diamonds. William Collins Sons \& Co., London, p.8.

Balfour I. (1997) Famous Diamonds. Christie, Manson \& Woods, London.

Bauer M. (1932) Edelsteinkunde. Bernhard Tauchnitz, Leipzig.

Ein berühmter Steinerner Gast an den Musikfestwochen [A famous stone as guest at the music festival] (1963) Luzerner Neueste Nachrichten, August 16.

Bharadwaj M . (2002) Great Diamonds of India. India Book House Pvt., N ariman Point, M umbai.

Biehn H. (1965) Juwelen und Preziosen [Precious Jewels]. Prestel Verlag, Munich, pp. 366-368.

Bissinger M., Lebeck R. (1971a) Die Helmut-Horten-Story [The Helmut Horten Story, part one]. Stern, M arch 28.

Bissinger M., Lebeck R. (1971b) Wir leben nicht wie Lieschen Müller [The Helmut Horten Story, part two: We are not living like Lieschen M üller]. Stern, A pril 4.

Der "Blaue Wittelsbacher" soll wieder nach München [The Blue Wittel sbach should come back to M unich] (1964) Abendzeitung, October 13.

Brunner H. (1970) Schatzkammer der Residenz München [Treasury of the Munich Residence], 3rd ed. Bavarian Administration of Castles, Gardens and Lakes, Munich.

Brunner H. (1977) Die Kunstschätze der Münchner Residenz [The Treasures of the Munich Residence]. Edited by A. Müller, Süddeutscher Verlag, Munich.

Bruton E. (1981) Diamonds. N .A.G. Press, London.

Burgerwelzijn (1962) Waarom wordt blauwe diamant uit Gulden Vliestentoonstelling geweerd? [Why was the blue diamond excluded from the Golden Fleece Exhibition?]. Burgerwelzijn, July 14.

Christie, Manson \& Woods (1931) Catalogue of the Bavarian Crown Jewels, the property of the Royal House of Wittel sbach, comprising Magnificent Brilliants and Emeralds which will be sold by Auction by Christie, Manson \& Woods. Printed by William Clowes and Sons, London.

Christie's (2008a) The Wittel sbach Diamond: Unique royal history for sale at Christie's London in December. Press Release, N ovember 3. http://www.christies.com/presscenter/pdf/ 11042008/115110.pdf.

Christie's (2008b) Jewels: The London Sale (10 December 2008). Auction catal ogue, Christie, Manson \& Woods Ltd., London.

Christie's (2008c) Jewels: The London Sale. Press release, auction result highlights, December 10, London.

Copel and L.L., Liddicoat R.T., Benson L.B., M artin J.G.M., Crowningshield G.R. (1960) The Diamond Dictionary. Gemological Institute of America, Los Angeles.

Diebäcker J. (1966) Hortens heimliche Hochzeit am Rhein [Horten's private marriage on the Rhine]. Rheinische Post, August 3.

Dröschel R (1982) Der Grosse Blaue Diamant, Wittelsbacher Hausdiamant [The great blue diamond, diamond of the House of Wittel sbach]. Mitteilungen des Vereins für Heimatkunde im Landkreis Birkenfeld, Vol. 56, pp. 42-45.

Er rührte an den heiligen Gral dieser $\mathrm{N}$ ation [He touched the Holy Grail of the nation] (1972) Spiegel, N o. 24, June 5

Erichsen J.K., Heinemann K. (2006) Bayerns Krone 1806, 200 Jahre Königreich Bayern [Bavaria's Crown 1806, 200 Years Kingdom Bavaria]. Bavarian Administration of Castles, Gardens and Lakes, Munich.

Exposition Universelle et Internationale de Bruxelles [U niversal and International Exhibition of Brussels (general catalogue)] (1958). Puvrez, Brussels.

Exposition U niverselle et Internationale de Bruxelles (1961) Les Participations Étrangères et Belges [Foreign and Bel gian participants], Vol. 3. Etablissements Généraux d'Imprime, Brussels.

Gaal R.A.P. (1977) The Diamond Dictionary, 2nd ed. Gemological
Institute of America, Santa M onica, CA .

General Inventory of Archduchess Maria Antonia, September 22 (1685) Austrian State Archives Vienna, (HHStA FUK 1777, vidimierte A bschrift vom 22 September 1685) GZBKA2025771//0001-ÖSTA HHSTA/2007.

Glaser H. (1976) Kurfürst Max Emanuel, Bayern und Europa um 1700 [Elector Max Emanuel, Bavaria and Europe at 1700]. Catalogue of the Exhibition in the Old and the N ew Castle Schleissheim, July 2-October 3, 1976, Vol. 2, Hirmer Verlag, Munich.

De Grote Blauwe Diamant, Der Wittelsbacher bei Gübelin [The great blue diamond, the Wittelsbacher, with Gübelin] (1963) Luzerner Tagblatt, August 16.

Harlow G.E., Ed. (1998) The Nature of Diamonds. Cambridge University Press in association with American Museum of Natural History, N ew York.

Heiniger E.A., Heiniger J. (1974) The Great Book of Jewels. New York Graphic Society, N ew York.

Heym S. (1999) Bayerische Kronen und Juwelen [Bavarian Crowns and Jewels]. In G. Guadal upi, Ed., Schätze der Welt, Meisterwerke der Goldschmiedekunst vom Alten Ägypten bis Cartier [Treasures of the World, Masterpieces of Goldsmith Art from Egypt to Cartier], Karl Müller Verlag, Erlangen.

Jahresverzeichnis der Deutschen Hochschulschriften [Annual Index of German U niversity Publications] (1960-1970) Deutsche Bücherei, VEB Verlag, edited by the German Library, Leipzig.

King J.M., M oses T.M., Shigley J.E., Wel bourn C.M., Lawson S.C., Cooper M. (1998) Characterizing natural-color type Ilb blue diamonds. Gems \& Gemology, Vol. 3, N o. 4, pp. 246-268.

King J.M., Johnson E.A., Post J.E. (2003) Gem N ews International: A comparison of three historic blue diamonds. Gems \& Gemology, Vol. 39, N o. 4, pp. 322-325.

Kratzer H., Evers J. (2008) Das Ringen um den blauen Wittelsbacher [The wrestling over the Wittelsbach Blue]. Süddeutsche Zeitung, N ovember 5.

Kuballa W. (1964) Der Stein, der aus der Krone fiel [The Gem that fell from the Crown]. Süddeutsche Zeitung, N ovember 21/22.

Kurin R. (2006) Hope Diamond: The Legendary History of a Cursed Gem. Smithsonian Books in association with Harper Collins, N ew York.

Laureys E. (2006) Der Belgische Diamantsector [The Belgian diamond sector]. Science Connection, A pril 11, pp. 2-6.

Legrand J. (1981) Der Diamant, Mythos, Magie und Wirklichkeit [Diamond: Myth, Magic and Reality]. Herder, Freiburg, Germany.

Der Lotto-Gewinn des Jahres: Heidi Horten (3 Milliarden) [The lottery profit of the year: Heidi Horten (3 Billion)] (1994) Bunte, April 7.

M arriage contract between Emperor Leopold I and M argarita M aria [M argarita Teresa] (1663) December 18. Austrian State Archives, Vienna FUK 1729,1-2.

M orel B. (1988) Les Joyaux de la Couronne de France [The Crown Jewels of Francel. Michel, Paris.

M orel B. (2001) The diamonds of the European monarchies. In H. Bari and V. Sautter, Eds. Diamonds, In the Heart of the Earth, in the Heart of Stars, at the Heart of Power. Vilo International, Paris, p. 268.

N euhauser P. (1971) Horten und das 825 Millionen-Ding [Horten and the 825 Million object]. Konkret, October 7.

Official Guide to the Universal and International Exhibition of Brussels (1958) Desclée \& Co., Tournai, Bel gium.

Ottomeyer H. (1979) Die Kroninsignien des Königreiches Bayern [The Crown Insignia of the Kingdom of Bavaria]. Verlag Schnell \& Steiner, Munich.

Puhle M. (2006) Heiliges Römisches Reich Deutscher Nation. Von Otto dem Grossen bis zum Ausgang des Mittelalters [Holy Roman Empire of Germany. From Otto the Great to the End of the Middle Ages]. Exhibition catalogue, Vol. 1.1, Pima, Magdeburg, Germany. 
Reyburn S. (2008) Diamond sells for record $\$ 24.3$ million, defying slump. Bloomberg.com, December 10, www.bloomberg.com/ apps/news?pid=20601088\& sid=a5z_1QLCVudQ .

Schatzkammer der Münchner Residenz [Treasury of the Munich Residence] (1937) Bavarian State Administration of Castles, Gardens and Lakes, edited by H. Kreisel, University Book Printing, Dr. C. Wolf \& Son, Munich.

70 Jahre H. Horten [70 Years H. Horten] (1979) Welt am Sonntag, January 9.

de Smet K. (1963) The Great Blue Diamond, The Wittelsbacher, Crown Witness to Three Centuries of European History. Standaard-Boekhandel, Antwerp-Amsterdam.

Special Report: The World's Billionaires (2008) www.forbes.com/ lists/2008/10/billionaires08 The-Worlds-Billionaires CountryOfCitizen.html [date accessed $\mathrm{N}$ ovember 25, 2008].

Testamentary Bequest of Empress M argarita Teresa, M arch 23 (1673) Austrian State Archive Vienna, HHStA FUK 1745, 1 and 2, GZ2025771/0006-ÖSTA HHSTA/2006.

Testamentary Bequest of Archduchess M aria Antonia, December 12 (1692) Austrian State Archives Vienna, HHStA FUK 1793,1-4, GZÖSTA-2025771-0002-HHSTA/2007.

Tillander H. (1965) Six centuries of diamond design. Journal of
Gemmology, Vol. 9, No. 11, pp. 380-401.

Tillander H. (1995) Diamond Cuts in Historic Jewellery. Art Books International, London.

Untracht O. (1997) Traditional Jewelry of India. H. N. Abrams, N ew York.

Verkauf bayerischer Kronjuwelen [Selling of the Bavarian Crown Jewels] (1931). Münchner Neueste Nachrichten, N ovember 29, p. 3.

Webster R. (1994) Gems: Their Sources, Descriptions, and Identification, 5th ed. Revised by P. G. Read, ButterworthHeinemann, Oxford.

Wer hat denn Kaiser Karls Brilliant verkauft? [Who has sold the diamond of Emperor Charles?] (1962) Q uick, M ay 6, pp. 30-32.

Der "Wittelsbacher" in Luzern [The "Wittelsbacher" in Lucerne] (1963) Vaterland, August 16.

Widorn H. (1960) Die spanischen Gemahlinnen der Kaiser Maximilian II, Ferdinand III, und Leopold I [The Spanish wives of Emperor Maximilian II, Ferdinand III, and Leopold I]. PhD Thesis, University of Vienna.

Zipser A. (1991) So angelte ich mir Frau Horten (5 Milliarden), Der Kuss auf den $5 \mathrm{M}$ illiarden-M und [So I fished for M rs. Horten: The kiss on the DM 5 billion mouth]. Bunte, July 25.

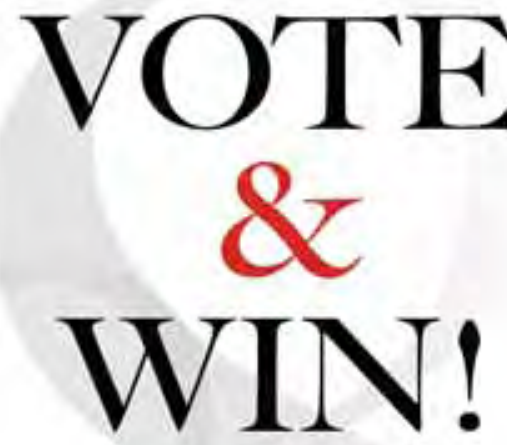

Simply tell us which three 2008 articles you found most valuable, and you could win a 3 -year subscription to

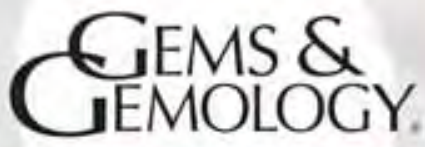

Plus FREE copics of al three volumes of

\section{The \\ Dr. Edward J. Gübelin Most Valuable Article Award}
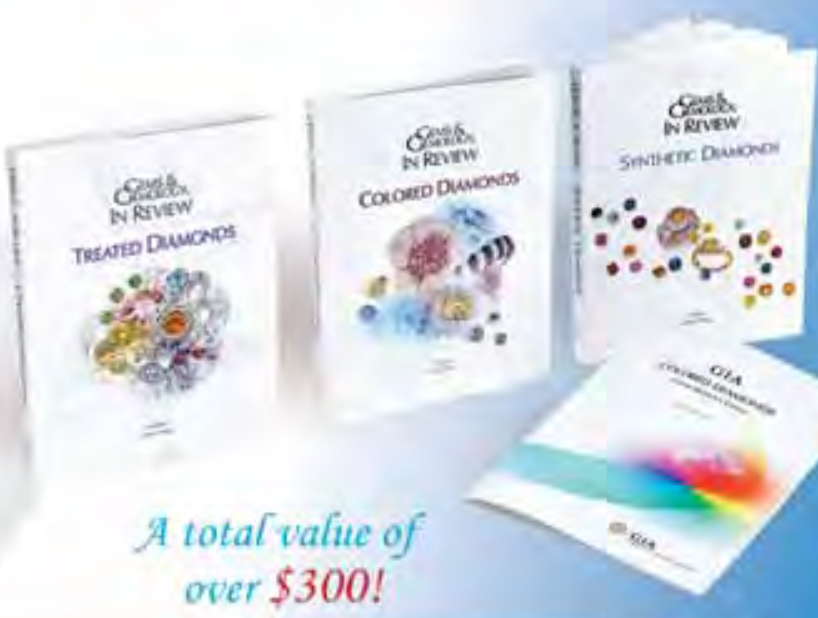

\section{GEMS \& JEMOLOGY. IN REVIEW}

Mark the artides in onder of preficence on the hallet cant betwezan

pages $34^{\circ} \&$ \&44. Then mail the card to arrive no bater than

March 6. 2000 and it will tecentered in a drawing for the grand price. 